\title{
BIOCLIMATIC FACTORS AFFECTING THE DISTRIBUTION OF QUERCUS ROBUR L. (PEDUNCULATE OAK) SUBSPECIES IN TURKEY
}

\author{
Osman Yalçın YILMAZ1, Hatice YILMAZ² \\ ${ }^{1}$ Department of Forest Engineering / Faculty of Forestry, University of İstanbul, Turkey \\ ${ }^{2}$ Ornamental Plant Cultivation Program, Vocational School of Forestry/ Faculty of Forestry, University of İstanbul, \\ Turkey \\ (yilmazho@istanbul.edu.tr)
}

\begin{abstract}
Understanding the distribution of individual species and the factors affecting their distribution is a key issue in biogeography, ecology and conservation. This study was carried out to determine bioclimatic factors affecting the two pedunculate oak subspecies (Quercus robur L. subsp. robur and Q. robur subsp. pedunculiflora (K.Koch) Menitsky) of Turkey and their tolerances to these factors.

Mean Temperature of Coldest Quarter (Bio 11), Temperature of Coldest Month (Bio 6), Temperature Annual Range (Bio 7), Temperature Seasonality (Bio), Precipitation Seasonality (Bio 15), Isothermality (Bio 3), Annual Mean Temperature (Bio1) are highly correlated bioclimatic variables that effect the distribution of pedunculate oak subspecies. Multinominal logistic regression result showed that the Bio4 is the only descriptor of the current distribution of subspecies robur and subspecies pedunculiflora.

The results also indicate that subspecies pedunculiflora shows a greater tolerance for extreme variation such as more drought summer and colder winters extreme variations during hot summers whereas subspecies robur is more sensitive to these climate variables.
\end{abstract}

Key words: bioclimatic tolerance range, pedunculate oak, subspecies, Turkey

\section{INTRODUCTION}

Plant species, like all other organisms, are able to function and reproduce in a set of environmental conditions. The range of variation which a species can survive and reproduce is defined as the tolerance range of it's for a particular environmental factor. The distribution of most terrestrial plant species in space and time is largely determined by limiting factors (e.g. temperature, precipitation and light), disturbances (natural or human induced), and resources (e.g. energy and water) (Guisan and Thuiller 2005). Plant distributions are limited when one environmental factor is lower than minimum required or more than maximum tolerance for a particular species (Billings 1952).

The central thesis of biogeography is that climate exerts the dominant control over the natural distribution of a species (Pearson and Dawson 2003). Plants can respond to climate 
change by shifting to suitable places to follow changing environments or by persisting in current location to adopt over generations to changing conditions or if neither of this occur, may become exist (Holt 1990). Species with narrow tolerance ranges tend to be more affected by climate change than species have wide tolerance ranges. Understanding the climatic tolerance of species is crucial to management and conservation of biodiversity (Hannah et al. 2002). Knowledge about the tolerances of the species allows us to make accurate predictions of species as a result of climate change. These predictions are important to develop forest management or biodiversity conservation plan under changing climatic conditions.

Quercus is one of the most important genus of woody plants in the Northern Hemisphere in terms of species diversity, ecological dominance, and economic value (Nixon 2006) and 400-500 species of the genus Quercus are important forest forming deciduous and evergreen trees of the Northern Hemisphere (Menitsky 2005). Oak trees are also major components of Turkey forests and 17 oak species are native to Turkey (Yllmaz 2014). Pedunculate oak is a wide spreading species throughout Europe, Caucasus, and Anatolia and has 4 subspecies currently described, including Q. robur subspecies robur, $Q$. robur subspecies pedunculiflora and $Q$. robur subspecies imeretina (Woronow) Menitsky and $Q$. robur subspecies brutia (Ten.) O.Schwarz (Govaerts and Frodin 1998). Two of them, subspecies robur and subspecies pedunculiflora grow in Turkey and they can be easily distinguished by morphology and geographic distribution (Hedge and Yaltırik 1982). The pedunculate oak distribution is characterized by a great altitudinal range in Turkey. Subspecies robur, a Euro-Siberian element, occurs in NW Turkey, Central Anatolia, South Anatolia and is scattered in deciduous forest, flood plains, steppe, often near streams between 100 and $1000 \mathrm{~m}$ asl. Subspecies pedunculiflora occurs in East and South East Anatolia in rocky slopes in moist places, between 1200 and $1800 \mathrm{~m}$ (Hedge and Yaltırk, 1982). The morphological differences of the two subspecies are that subspecies pedunculiflora has abaxial surfaces pubescent leaves with narrow and deep sinuses and a distinct petiole up to $20 \mathrm{~mm}$; the acorn has stout peduncle 2 to $6 \mathrm{~cm}$ while subspecies robur has subsessile leaves with a broad and shallow sinus and slender peduncle (2) 4-10 (12) $\mathrm{cm}$ (Hedge and Yaltırık 1982, Schwarz 1993).

Several studies were carried out to determine the ecological niche of some oak species in Turkey based on bioclimatic characterization (Dufour-Dror and Ertaş 2004, Kargioğlu et al. 2009, Serteser et al. 2009, Kargioğlu et al. 2011, Uğurlu et al., 2012, Uğurlu and Oreland, 2012). However ecological preferences of several oak species in terms of climate are still little known especially species grow in east and southeast Anatolia (Uğurlu et al 2012, Uğurlu and Olgeland 2012). Climatic factors affecting the distribution of $Q$. robur subspecies in Turkey has not been investigated up to now.

The aim of the study is to determine the bioclimatic variables affecting the distribution of two pedunculate oak subspecies in Turkey and illustrate their tolerances to these variables. Our main hypothesis is that significant differences between the bioclimatic tolerance ranges of the two subspecies may be found because they do not occur in the same area in Turkey. It is crucial to know the bioclimatic factors that influence the geographic distribution of a species to assess the ecological impact of climate changes. Understanding the ecological requirements and bioclimatic tolerance range of a species is also important for forest management and conservation efforts because this knowledge would contribute to reforestation and biodiversity conservation activities.

\section{MATERIAL AND METHODS}

Climate conditions were represented by 19 bioclimatic variables (Table 1) obtained from the WorldClim database v1.4 (Hijmans et al. 2005; www.worldclim.org). These data are a set of global climate layers with a spatial resolution of approximately $1 \mathrm{~km} 2$ grids (Hijmans et al., 2005). 
The WorldClim dataset was generated a thin-plate spline interpolation technique using altitude, and monthly temperature, and precipitation records from long term (1950 to 2000). The 19 bioclimatic variables represent annual trends, seasonality and extreme or environmental factors (www.worldclim). Therefore, using these data are considered biologically more meaningful in defining the ecophysiological tolerances of a species rather than using simple monthly or annual averages of temperature and precipitation (Nix 1986, Kumar et al. 2009).
We used presence records of two subspecies from ISTO Herbarium and the "Flora of Turkey and East Aegean Islands" (Hedge and Yaltırık 1982). The locality description of the species presences was converted to point vector layer through geocoding function of Quantum GIS (QGIS Development Team 2015) using Google web services (Figure1). All bioclimatic variables values were uploaded into the point vector layer of species locations. After bioclimatic values uploaded to the GIS vector layer, they were imported to $\mathrm{R}$ statistical environment ( $\mathrm{R}$ Development Core Team 2015).

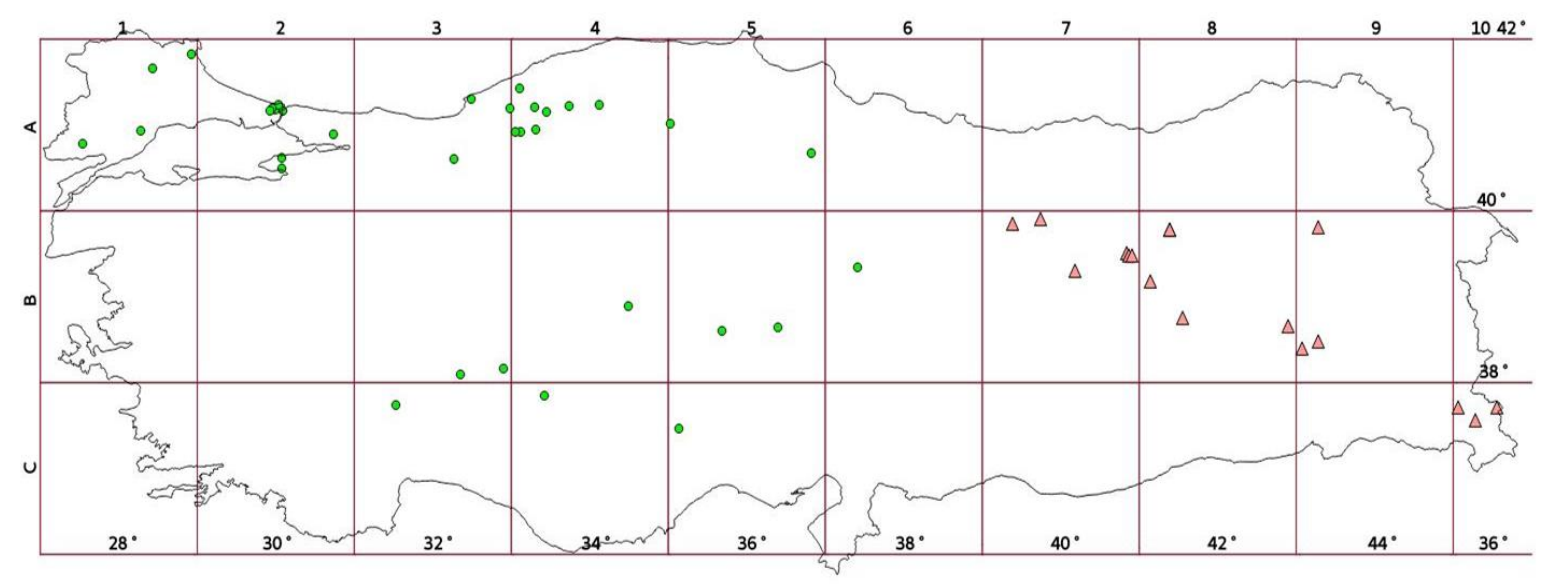

Figure 1 Presences of the studied subspecies in Turkey. Q. robur subsp. pedunculiflora (red triangle), $Q$. robur subsp. robur (green circle)

To explore relationship between subspecies and bioclimatic variables we used bivariate scatter-plots of these variables. We calculated point biserial correlation coefficients between species and bioclimatic variables (Table 1). To explain tolerances of these subspecies in a better way, we used multinomial logistic linear regression analysis to fit models between response and terms. To handle multicollinearity of bioclimatic variables we used simple five steps way suggested by Kuhn and Johnson (2013) and used remaining bioclimatic variables to fit model.
After fitting logistic regression model we determined the best model with stepwise backward/forward model selection according to Akaike Information Criterion (AIC) score. AIC compares multiple competing models all at once and the model with the lowest AIC value being the best model (Burnham and Anderson, 2002). Figure 2 illustrates the steps used in the study. We conducted our analyses using the $\mathrm{R}$ ( $\mathrm{R}$ Development Core Team 2015) and Quantum GIS software (QGIS Development Team 2015). 

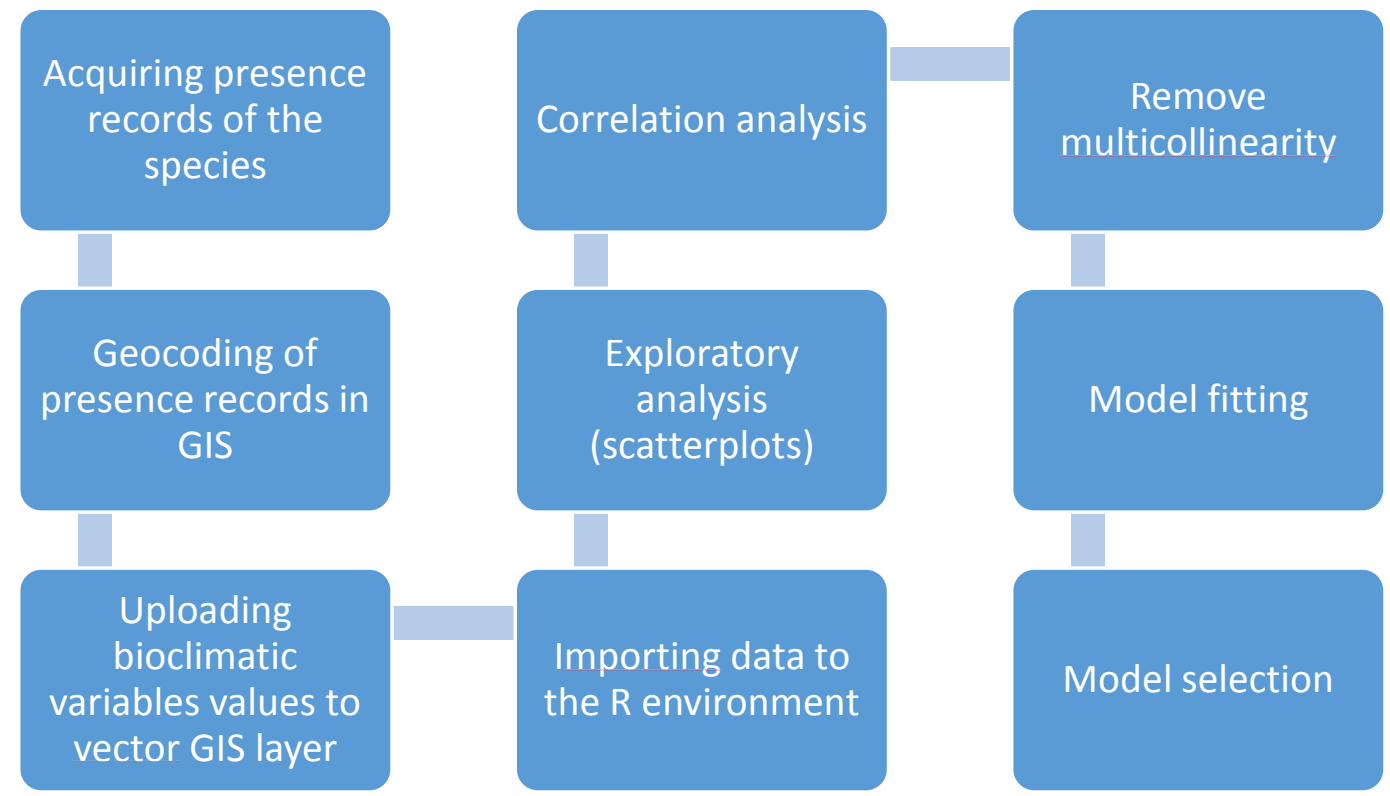

Figure 2. Diagram indicating the proposed methodology used in this work

Table 1. A list of the 19 bioclimatic variables used in this study derived from WORLDCLIM (Hijmans et al., 2005) data set. Biserial correlation coefficients were also given for the subspecies.

\begin{tabular}{|c|c|r|}
\hline $\begin{array}{c}\text { Abbre- } \\
\text { viation }\end{array}$ & Bioclimatic variable description & r2 \\
\hline Bio1 & Annual mean temperature & 0.66 \\
\hline Bio2 & $\begin{array}{l}\text { Mean diurnal temperature range (mean of monthly maximum tempera- } \\
\text { ture minus minimum temperature) }\end{array}$ & - \\
\hline Bio3 & Isothermality (Bio2/Bio7 x 100) & - \\
\hline Bio4 & Temperature seasonality (standard deviation of monthly temperature) & 0.30 \\
\hline Bio5 & Minimum temperature of the coldest month & - \\
\hline Bio6 & Maximum temperature of the warmest month & 0.88 \\
\hline Bio7 & Temperature annual range (maximum temperature of the warmest month & - \\
\hline Bio8 & minimum temperature of the coldest month) & 0.79 \\
\hline Bio9 & Mean temperature of wettest quarter (i.e. mean temperature of four con- & 0.80 \\
\hline Bio10 & Mecutive wettest months) & - \\
\hline Bio11 & Mean temperature of driest quarter & 0.29 \\
\hline
\end{tabular}




\begin{tabular}{|l|l|r|}
\hline Bio12 & Annual precipitation & - \\
\hline Bio13 & Precipitation of wettest month & 0.10 \\
\hline Bio14 & Precipitation of driest month & - \\
\hline Bio15 & Precipitation seasonality (standard deviation of monthly precipitation) & 0.15 \\
\hline Bio16 & Precipitation of driest quarter & 0.56 \\
\hline Bio17 & Precipitation of wettest quarter & - \\
\hline Bio18 & Precipitation of warmest quarter & - \\
\hline Bio19 & Precipitation of coldest quarter & 0.19 \\
\hline & & 0.59 \\
\hline & & 0.67 \\
\hline
\end{tabular}
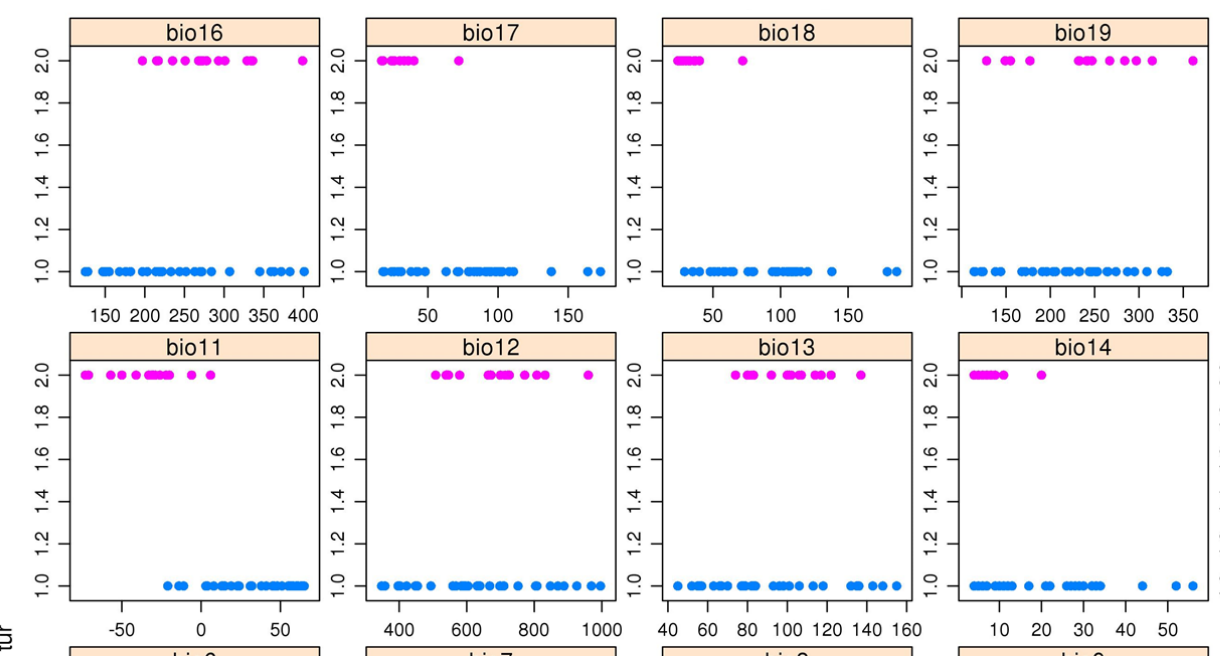

$\begin{array}{lllll}150 & 200 & 250 & 300 & 350\end{array}$
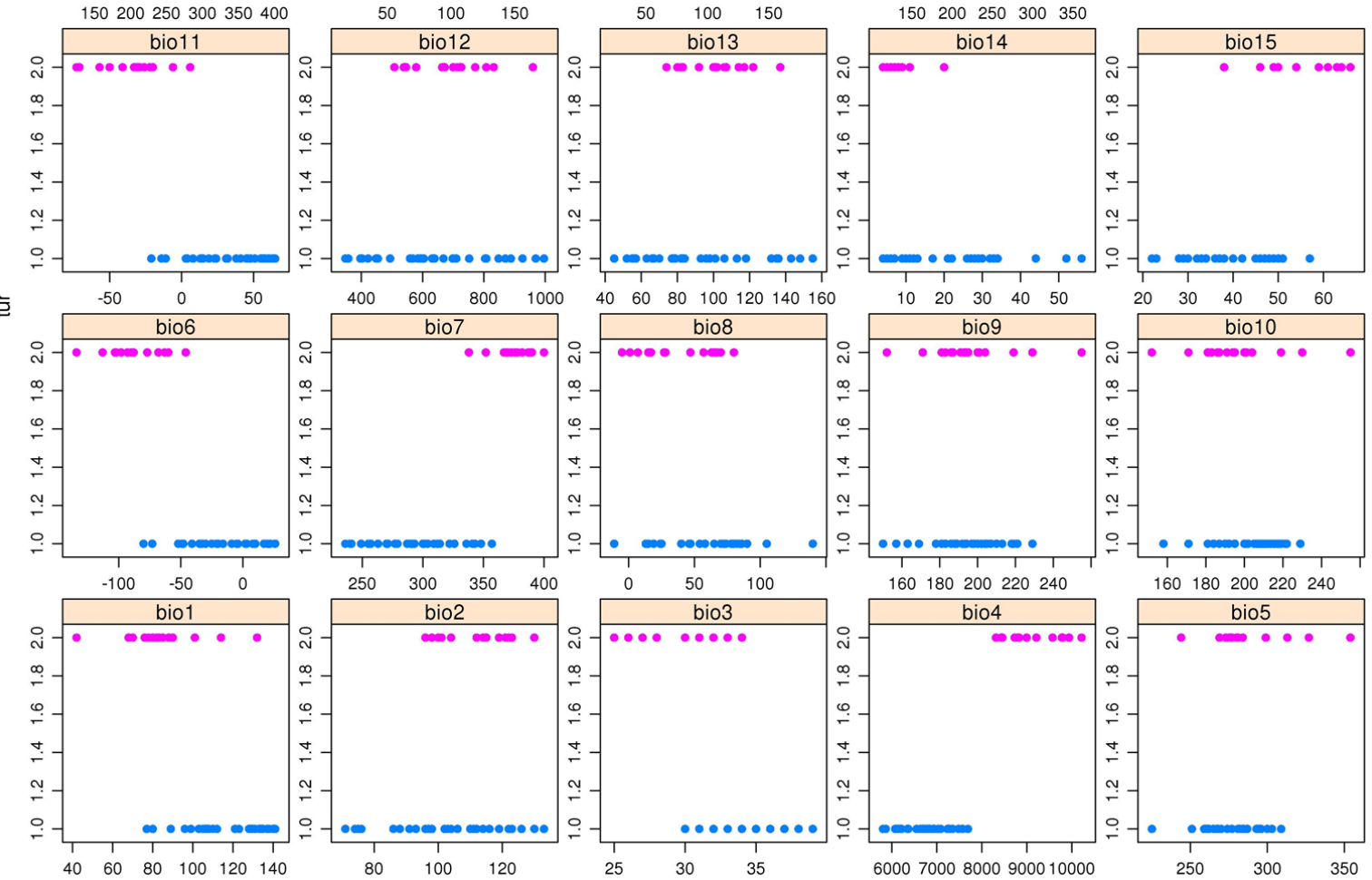

Figure 3. Bivariate scatterplots of species presences as a function of bioclimatic variables. Q. robur subsp. pedunculiflora (pink circle), Q. robur subsp. robur (blue circle) 


\section{RESULTS AND DISCUSSION}

The analysis of the bioclimatic factors and distribution range of the two pedunculate oak subspecies showed that the distribution of these subspecies is controlled mainly by temperature and precipitation variables. Comparison of bioclimatic envelops for the two subspecies suggests that there are some similarities in climatic requirements but also many important differences.

Bivariate scatterplots of 19 variables showed that there were 4 factors that mostly influenced the two subspecies' distribution: Mean Temperature of Coldest Quarter (Bio 11), Minimum temperature of the coldest month (Bio 6), Temperature Annual Range (Bio 7), Temperature Seasonality (Bio 4) (Figure 3). Precipitation Seasonality (Bio 15), Isothermality (Bio 3), Annual Mean Temperature (Bio 1) are also important bioclimatic variables that effect

Subspecies pedunculiflora can grow higher annual temperature range (Bio7), lower mean temperature of coldest quarter (Bio 11) lower minimum temperature of the coldest month (Bio 6) and lower annual mean temperature (Bio 1), than subspecies robur. Isothermality (Bio 3) (can be interpreted as the evenness of temperature over the course of a year temperature evenness) is also lower in subspecies pedunculiflora range areas.

The point biserial correlation analysis showed that the distribution of subspecies is also correlated with precipitation. Precipitation seasonality (Bio15) $\mathrm{r} 2=0.65$ and precipitation in the warmest quarter (bio18) $\mathrm{r} 2=0.67$ are the variables that related with distribution of the subspecies. Subspecies pedunculiflora tolerates lower precipitation of warmest quarter (Bio 18), higher precipitation seasonality (Bio 15).

After fitting multinominal logistic regression model with 9 bioclimatic variables that do not show multicollinearity, we determined best model with stepwise backward/forward model selection according to Akaike Information the distribution of pedunculate oak subspecies. Bivariate scatter-plots give valuable information about these subspecies' bioclimatic preference, the biserial correlation results also showed similar results. According to point biserial correlation analysis, correlation coefficients between species presences and bioclimatic variables higher than 0.6 are ranked from the highest to the lowest Bio4 (0.88), Bio7 (0.80), Bio11 (-0.8), Bio6 (-0.79), Bio3 (-0.69), Bio18 (-0.67), Bio1 (-0.66), Bio 15 (0.65) (Table 1). Bio 4 (temperature seasonality) is the highest correlated variable on the distribution of the subspecies. Subspecies robur prefer the moderate temperature seasonal variation while subspecies pedunculiflora tolerates the seasonal temperature extremes. The habitat suitability of subspecies pedunculiflora increased slowly with increases in temperature seasonality. Temperature Annual Range (Bio 7) is the second and mean temperature of coldest quarter (bio11) is the third most important variable affecting the distribution of the two subspecies.

Criterion (AIC) score Result showed that the Temperature Seasonality (Bio 4) is the only remaining variables and a strong association with the distribution of Q. robur subspecies robur and Q. robur subspecies pedunculiflora. The model showed that temperature seasonality (Bio 4) is the most important climatic variable that potentially limits the spread of two pedunculate oak subspecies in Turkey. Subspecies pedunculiflora prefer temperature seasonality (standard deviation *100) greater than $80{ }^{\circ} \mathrm{C}$ while subspecies robur grow less than $80^{\circ} \mathrm{C}$. The habitat suitability of subspecies pedunculiflora increased slowly with increases in temperature seasonality. Subspecies pedunculiflora is unable to tolerate lower temperature seasonality and subspecies robur is also unable to tolerate higher temperature seasonality. Tolerances of individual species for extreme seasonality are generally conserved across phylogeny. Therefore, temperature seasonality can be used to accurately predict the range limits of species in species distribution models (SDMs) (Wiens et al. 2006).

Point biserial correlation analysis and multinominal logistic regression identified 
temperature seasonality as the strongest climatic variable that determined the distribution of subspecies.

From an ecological perspective, bioclimatic niche of the two subspecies are very distinct from each other. Their main differences are in their ability to tolerance to seasonal variations in temperature (Bio4), extreme annual temperature variations (Bio 4, Bio3, Bio7) and to deal with hot dry season (Bio 8 and Bio 15). In terms of temperature and precipitation, there are main differences between the tolerance range of the two subspecies. The study highlighted that subspecies pedunculiflora can tolerate greater seasonal temperature variability, higher ranges of extreme temperate conditions, greater seasonal precipitation variability and less precipitation in hottest season. The results indicate that subspecies pedunculiflora is significantly higher tolerance range of seasonal variations in temperature, greater tolerance range temperature extremes and more drought tolerant whereas subspecies robur is more sensitive to these climatic variables. The absence of the subspecies pedunculiflora east of Anatolian Diagonal (Uslu and Bakış, 2012) might be explained that its distribution is actually limited by the lower precipitation in warmest quarter, more irregular rainfall regime and greater seasonal variations in temperature.

\section{CONCLUSION}

The distribution of Quercus robur' subspecies in Turkey is not random but is determined by the niche of each subspecies and availability of habitat necessary for survival. They do not grow in the same area and each subspecies has its own ecological preferences, determined by their climatic optima.

Our results have particularly important implications for application of niche-based species distribution models to predict distribution model of the subspecies evaluating climate change scenarios in Turkey.

As a further step, our result could provide a frame work to design studies to determine bioclimatic tolerances of Quercus robur subspecies' in whole distribution area and some strategies can be developed into conservation policy, planning and practice in light of climate change. The ability to adapt to climate which more drought and greater temperature variations of subspecies pedunculiflora may become an important issue with regard to global climate change (Curtu et al 2011), because it is thought that increasing temperature would lead to vegetation shifts upwards to higher altitudes and northern latitudes (Melilleo et al, 1990).

However further investigation is needed to understand the effect of the other factors because range limits may be different in different parts of its range and set by complex interactions between biotic and abiotic factors in other parts of the world.

\section{Yapılandırılmı̧̧ Özet}

Önem: Bir türün yerel ölçekte yayılışını etkileyen iklim parametrelerinin belirlenmesi, doğal kaynakların yönetimi, restorasyon çalışmaları, biyolojik çeşitliliğin konrunması ve iklim değişikliği etkilerinin değerlendirilmesi bakımından önemlidir.

Amaç ve Hedef: Türkiye'de doğal olarak yetişen 17 meşe türünden biri olan Quercus robur (saplı meşe) iki alttür ile temsil edilmekte olup bu çalışmada alttürlerin yayılışını etkileyen iklim faktörlerinin belirlenmesi amaçlanmıştır. Türkiye'de coğrafi olarak kesin sınırlarla ayrılan bu iki alttürün biyoklimatik faktörlere tolerans sınırlarının ortaya konması hedeflenmiştir. 
Materyal: Çalısmada ISTO herbaryum kayıtları ile Flora of Turkey'de yer alan kayıtlar var verisi olarak alınmış, iklim verisi olarak WorldClim database v1.4 (Hijmans et al., 2006; www.worldclim.org)' den elde edilen 19 biyoklimatik değişken kullanılmıştır.

Metot: Türlere ait herbaryum kayıt verilerindeki konum bilgileri QGIS yazılımının "geocoding" fonksiyonu yardımıyla coğrafi koordinatlara dönüştürülerek vektör coğrafi bilgi sistemi katmanı oluşturulmuştur. Oluşturulan bu dosyaya 19 adet biyoiklim raster verisine ait bilgiler yüklenmiştir. R istatistik ortamına aktarılan veriler ile önce ikili-saçılım grafıği ile keşif analizi yapılmışır. Point biserial korelasyon ile türlerle iklim değişkenleri arasındaki korelasyonlar belirlenmiş ve multinomial logistic linear regresyon ile de model oluşturulmuştur.

Bulgular ve Tartışma: İki alttürün dağılışı ve iklim verileri analiz edildiğinde bu taksonların Türkiye'deki yayılışını yağış ve sıcaklı̆̆ın kontrol ettiği belirlenmiştir. "Point biserial correlation" analizine göre mevsimsel sıcaklık varyasyonu (Bio 4) iki alttürün yayılmasını sınırlayan en önemli biyoiklim değişkeni olarak bulunmuştur. Bio 4, Bio 3 ve Bio 7 sıcaklıklarda mevsimsel değişimi ölçen değişkenler olup subspecies pedunculiflora'da yüksek değerler olarak bulunmuştur. Sıcak mevsimdeki yağış miktarı ve yil boyunca aylık yağış farklılıkları yayılışı etkileyen yağ1ş faktörleri olarak tesbit edilmiştir. Subspecies robur mevsimsel sıcaklık farklılıklarına, kuraklığa, düzensiz yağış rejimine daha az tolerans gösterirken subspecies pedunculiflora extrem değerlere dayanabilmekte ve sıcaklıklarda mevsimsel farklar biraz yükseldiğinde bu alttürün habitat uygunluğu da artmaktadır.

Sonuç: Saplı meşe alttürlerinin Türkiye'deki yayılışının tesadüfi olmadığı, her iki alttürün ekolojik isteklerinin farklı olduğu belirlenmiştir. Subspecies pedunculiflora kuraklığa, sıcaklık ektrem değerlerine ve mevsimsel sıcaklık farklılıklarına subspecies robur'dan daha dayanıklıdır. Bu alttürün kurak çevre koşullarına uyum kabiliyeti, kuraklık ve ekstrem sıcaklıklara yüksek toleransı küresel iklim değişikliğinin etkileri göz önüne alındığında çok önemlidir. Bu sonuçlar koruma, ağaçlandırma ve orman amenajmanı çalışmalarında fayda sağlayacaktır.

\section{References}

Billings, D. (1952). The environmental complex in relation to plant growth and distribution. The Quarterly Review of Biology, 27, 251-265.

Burnham, K.P., Anderson D.R. (2002). Model selection and multimodel inference: a practical information theoretic approach. Springer, Berlin

Curtu, A.L., Sofletea, N., Toader, A.V., Enescu, M.C. (2011). Leaf morphological and genetic differentiation between Quercus robur L. and its closest relative, the drought tolerant Quercus pedunculiflora K. Koch. Annals of Forest Science, 68, 1163-1172.

Dormann, C.F., Elith, J., Bacher, S., Buchmann, C., Carl, G., Carre, G., Marquez, J.R.G., Gruber, B., Lafourcade, B., Leitao, P.J., Munkemuller, T., McClean, C., Osborne, P.E., Reineking, B., Schroder, B., Skidmore, A.K., Zurell, D., Lautenbach, S., (2013). Collinearity: a review of methods to deal with it and a simulation study evaluating their performance. Ecography, 36 (1), 27-46.

Dufour-Dror, J.M., Ertaş, A. (2004). Bioclimatic perspectives in the distribution of Quercus ithaburensis Decne. subspecies in Turkey and in the Levant. J Biogeogr 31: 461-474.

Govaerts, R., Frodin, D. G. (1998). World checklist and bibliography of Fagales.Royal Botanic Garden, Kew UK, pp. 407.

Guisan, A., Thuiller, W. (2005). Predicting species distribution: offering more than simple habitat models. Ecology Letters, 8, 9931009.

Hedge, I., Yaltır1k F. (1982). Quercus L. In: Davis, P.H. (Ed.) Flora of Turkey and East Aegean Islands. Edinburgh University Press, Edinburgh, Vol. 7, pp. 560-589.

Hijmans, R.J., Cameron, S.E., Parra, J.L., Albert, D.L. (2005). Very High resolution interpolated climate surfaces for global land areas. 
International Journal of Climatology, 25, 1965-1978.

Holt, R.D. (1990). The microevolutionary consequences of climate change. Trends in Ecology \& Evolution, 5,311-315.

Kargioglu, M., Senkul, C., Serteser, A., Konuk, M. (2009). An assessment on bioclimatic requirements of endemic Quercus vulcanica (Boiss. and Heldr) Kotschy communities living in different phytogeographic regions of Turkey. Polish Journal of Ecology, 57, 197-200.

Kargioglu, M., Serteser, A., Senkul, C., Konuk, M. (2011). Bioclimatic characteristic of oak species Quercus macranthera subsp. syspirensis and Quercus petraea subsp. pinnatiloba in Turkey. Journal of Environmental Biology, 32, 127131.

Kuhn, M., Johnson, K. (2013). Applied Predictive Modeling. Springer, New York, USA, pp. 600 .

Kumar, S., Spaulding, S.A., Stohlgren, T.J., Hermann, K.A., Schmidt, T.S., et al., (2009). Potential habitat distribution for the freshwater diatom Didymosphenia geminata in the continental US. Frontiers in Ecology and the Environment, 7 (8), 415-420.

Melillo, J.M., Callaghan, T.V., Woodward, F.I, Salati, E.,Sinha, S.K. (1990). Effects on ecosystems. In: J.T. Houghton, G.J. Jenkins, J.J. Ephraums (Eds.), Climate Change: the IPCC Scientific Assessment, University Press, Cambridge, pp. 283-310

Menitsky, Y.L. (2005). Oaks of Asia.Science Publishers, Enfield (NH), USA, pp. 549.

Nix, H.A., 1986. A biogeogaphic analysis of Australian Elapid snakes. In: Longmore, R. (Ed.), Australian Flora and Fauna Series, 8. Australian Government Publishing Service, Canberra, Australia, pp. 4-15.

Pearson, R.G., Dawson, T.P. (2003). Predicting the impacts of climate change on the distribution of species: Are bioclimate envelope models useful? Global Ecology and Biogeography, $12,361-71$

QGIS Development Team (2015). QGIS Geographic Information System. Open Source Geospatial Foundation Project. http://www.qgis.osgeo.org. (Visited on date:10 /11/ 2015).
R Development Core Team (2015). A language and environment for statistical computing. R Foundation for Statistical Computing. Vienna, Austria. http:/ /www.R-project.org/. (Visited on date:10/11/ 2015).

Schwarz, O. (1993). Quercus L. In: Tutin, T.G., Burges, N.A., Chater, A.O. (Eds) Flora Europaea. Cambridge University Press, Cambridge, pp 72-76.

Serteser, A., Kargioglu, M., Senkul, C., Konuk, M. (2009). An assessment on bioclimatic requirements of endemic Quercus aucheri Jaub. and Spach. communities spreading southwest Anatolia. Asian Journal of Plant Science, 8, 35-41.

Ugurlu, E., Rolecek, J., Bergmeier, E. (2012). Oak woodland vegetation of Turkey - a first overview based on multivariate statistics. Applied Vegetation Science, 15. 590-608.

Ugurlu, E., Oldeland, J. (2012). Species response curves of oak species along climatic gradients in Turkey. International Journal of Biometeorology, 56, 85-93.

Uslu, E., Bakış, Y. (2012). Geographic distribution of Turkish Oaks. Dendrobiology, 67,41-48.

Wiens, J.J., Graham, C.H., Moen, D.S., Smith, S.A., Reeder, T.W. (2006). Evolutionary and ecological causes of the latitudinal diversity gradient in hylid frogs: treefrog trees unearth the roots of high tropical diversity. American Naturalist, 168, 579-596.

WorldClim database. Available at http://www.worldclim.org (Visited on 09/11/2015)

Yilmaz, H. (2014). Quercus L. In: Akkemik Ü. Türkiye'nin Doğal-Egzotik Ağaç ve Çalıları I. Orman Genel Müdürlügü Yayınları, Ankara, pp. 673-702.

Submitted: 23.06.2016

Accepted: 12.07.2016 